\title{
Pension Reform in Brazil: Transitional Issues in a Model with Endogenous Labor Supply*
}

\author{
Sergio Guimarães Ferreira**
}

\begin{abstract}
Brazilian PAYG system has been under financial stress and needs to be reformed. A computational general equilibrium model with 55 overlapping generations is used to simulate macroeconomic and welfare impacts of alternative social security reforms. Transition turns out to have quite different redistributional effects for the generations involved depending on which tax is used to finance it. There is no unanimity about which transitional tax path maximizes individual welfare. I study potential voting results if generations choose between the PAYG and a set of transitional schemes.
\end{abstract}

Keywords: Social Security, Welfare, General Equilibrium, Macroeconomics, Overlapping Generation.

JEL Codes: E62, D58, D91.

\footnotetext{
${ }^{*}$ Submitted in September 2003. Revised in January 2006.

** IBMEC-RJ and BNDES. I am deeply in debt with Rodolfo Manuelli for his comments in several versions of this paper. I thank as well two anonymous referees and participants of the workshops at UW-Madison, IBMEC-RJ, IPEA-RJ and IBMEC-SP. I am fully accountable for any remaining mistakes or omissions in this paper. I thank CNPq for the financial support that made this research possible. The opinions contained in this paper do not represent necessarily those of BNDES. E-mail: sferreira@ibmecrj.br
}

Brazilian Review of Econometrics

v. $26, \mathrm{n}^{\circ} 1$, pp. $127-153 \quad$ May 2006 


\section{Introduction}

The Brazilian social security budget has been running a deficit since 1996. Moreover, the combination of increasing retirement benefits and stable revenues has been driving up continuously such deficit to reach $1.82 \%$ of the GDP in $2004 .^{1}$ This deficit is mainly a result of the Constitution of 1988, which enlarged the program without a parallel and substantial increase in social security tax revenues. Besides, the impact of demographics over the future social security deficit is substantial. ${ }^{2}$

This paper primarily studies the several alternatives to reforming the PAYG, and its transitional impacts on the well being of the generations alive during the transition. A general equilibrium model with 55 overlapping generations, adapted to Brazilian institutions and deep parameter values, is used to look into these problems.

It is well known that, in the absence of uncertainty, the impact of a social security program on labor supply, capital accumulation and individual welfare will depend on the magnitude of the replacement, yield and retirement effects, as defined by Kotlikoff (1979) and Feldstein (1974). In addition, general equilibrium effects complicate the analysis up to a point where computation is required to find the net impact of social security reforms on individual welfare.

The first important finding of this paper is that, under a wide range of parametric assumptions that match Brazilian characteristics for the life cycle wage profile, technological and preference parameters, the elimination of the PAYG system may bring large welfare improvements. ${ }^{3}$ In addition, the welfare gains are still substantial in the long run when the retirement benefits are diminished to only $30 \%$ of the status quo level. This means that reforms that keep a minimum retirement benefit in order to insure bad income draws, as done by Chile and Mexico, among others, are still able to get sizeable welfare increases. Moreover, even when the

\footnotetext{
${ }^{1}$ Such sentence must be put into perspective. The actual deficit of the defined-benefit, oldage, social security system must include LOAS as benefits and exclude expenses not linked to old age. Some old-age benefits in Brazil are not financed by the social security labor tax. For example, the retirement benefits for individuals older than 65 , who prove to have a per capita family income lower than $\frac{1}{4}$ of the minimum wage, called LOAS benefits, are financed by general taxes. Such expenses have been increasing at very high rates recently, reaching $0.29 \%$ of the GDP in 2004. Some other expenses not linked to retirement benefits but to other contingencies (mainly maternity, illness, work-related accidents) are attributions of the social security agency (INSS). Such expenses were about $0.82 \%$ in 2003 . Hence, calculation of the strict social security deficit leads to a figure of $1.42 \%$ of the GDP.

${ }^{2}$ The proportion of the population aged over 60 was $8.9 \%$ in 2005 and will be $17.1 \%$ in 2030 . Ardeo et al. (2004) prognosticate that demographics will be responsible for an increase in benefits to $10 \%$ of the GDP in 2030, assuming that the economy develops at an annual growth rate of $3 \%$.

${ }^{3}$ Elimination and privatization of social security are interchangeable terms in this paper. Privatization here refers to the shift from unfunded PAYG programs to funded programs with individual accounts.
} 
only reform is a switch in the tax base financing social security, it is possible to obtain substantial rise in welfare. That is the case when the retirement benefits are financed by a consumption tax instead of by the benchmarking labor tax.

The second type of findings in this paper relates to transitional issues. In the majority of the reforms in this paper, individuals will earn retirement benefits that are proportional to their contributions to the system. Hence, the aggregate retirement benefits smoothly decrease, reaching zero when the last contributor dies. Meanwhile, the social security tax is eliminated instantaneously for most of the simulated reforms. The way the remaining benefits are financed, either by adjusting some other tax or by running a deficit, will imply a completely different distribution of the welfare impact across the living generations. The switch in the tax base and the elimination of benefits will cause large intergenerational redistribution.

Under the assumed parametric settings, the initial elderly will suffer most from a switch to consumption tax since they have higher marginal propensity to consume over their lifetime income. A switch to capital tax imposes the largest welfare losses over the middle-aged and elderly individuals, since these groups earn most of their income from assets. A switch to labor tax works as a gradual elimination of the payroll tax, and hence it is the most equitable alternative. The accumulation of debt in order to finance the retirement benefits is a way of transferring the welfare losses toward unborn individuals, since the tax adjustment will eventually be done, and will affect mostly the future generations.

General equilibrium effects are very important to understand the welfare impacts across generations. For example, the elderly would rather have a transition financed by debt in the first years than stay in the status quo system. This is due to the positive short run impact of the reform over the interest rate, and then, over the returns on the assets they own. Since they will no longer be alive by the time of the tax adjustment, their welfare gain under the remaining lifetime will be substantial. Comparatively, the initial youths prefer reforms that lead to fast capital accumulation and to higher real wages.

The actual implementation of a given type of reform will be a matter of building political coalitions. If voters do not care about the utility level of their offspring, the short run macroeconomic impacts of the reform will define the preferences and the political support over the spectrum of optional tax policies. In fact, if agents were myopic, the welfare gains and losses predicted by the model would be an indication of political outcome. 
Simulations that use the actual Brazilian demographic distribution show, first, that none of the proposed reforms is strictly preferred by every agent. In other words, there is no unanimity over the spectrum of possible transitions. Secondly, every transitional tax path is preferred by at least one living generation at the moment the reform starts. Thirdly, the status quo PAYG enjoys substantial political support from middle-aged and elderly individuals when debt accumulation and pre-announcement are excluded from the menu options.

Other authors have used similar procedures to analyze social security privatization in Brazil, but either with simplified parametric assumptions or assuming exogenous labor supply. The closest substitute is Barreto and Oliveira (2000) who also deal with the macroeconomic effects of social security privatization in Brazil by using a model where the labor supply is treated exogenously. ${ }^{4}$

This paper is divided into seven sections. Section 2 presents the model. Section 3 presents the criteria for calibrating the initial steady state. Section 4 describes the alternative experiments. Section 5 studies the long run effects of eliminating the social security tax and the system of retirement benefits. Section 6 goes through the macroeconomic and welfare analysis of the transition. Section 7 concludes.

\section{The Model}

This section gives an overview of the general equilibrium model with 55 overlapping generations, used in the simulations of the social security reforms, which is an adaptation of Auerbach and Kotlikoff (1987) to the Brazilian social security system. ${ }^{5}$ Consumers maximize preferences over a 55 -year life cycle. They become eligible for retirement benefits at age 45 , get their first retirement benefit at 46 , and die at 56 years old. For an individual born at time $t$ and aged $j$ years old, the time-additive utility function takes the form

$$
\left(c_{t+j, j} l_{t+j, j}\right)=(1 / 1-1 / \gamma) \sum_{j=1}^{55}(1+\delta)^{-j}\left\{\left[c_{t+j, j}^{(1-1 \rho)}+\alpha l_{t+j, j}^{(1-1 / r h o)}\right]^{1 /(1-1 / \rho)}\right\}^{1-1 / \gamma}
$$

\footnotetext{
${ }^{4}$ Ellery and Bugarin (2002) apply the model of Huang et al. (1997) to the Brazilian case to compare steady states under different social security systems. In their model, there is uncertainty about labor income (with the possibility of unemployment spells) and about life expectancy. A recent paper by Shiller (2005) adds uncertainty about savings accounts returns. Deaton et al. (2000) also add uncertainty about interest rate and labor earnings in a welfare analysis comparing steady states with different social security systems. Such papers find that welfare improvements by capitalizing the system is much less clear-cut than those obtained without uncertainty.

${ }^{5}$ The AK model has the disadvantage of disregarding the important aspect of the insurance role of a sure retirement income. However, such simplification makes the programming simple enough to allow the analysis of transition. Alternatively, other general equilibrium models incorporate uncertainty about life expectancy but do not look into transitional aspects of the reform (e.g., De Nardi et al. (1998) and Huang et al. (1997)).
} 
where $c_{t+j, j}$ is his/her consumption of an aggregate consumption good and $l_{t+j, j}$ is his/her leisure demand. The household budget constraint depends on the current and future values of the interest rate and wage rate. In addition, it will depend on the future path of consumption, capital, and labor taxes. The model assumes that there is no uncertainty about such paths and no borrowing constraints.

$$
\begin{aligned}
P V B_{t}+ & \sum_{j=1}^{55}\left\{\Pi_{s=1}^{j}\left[\left(1+r_{t+s}\right)\left(1-\tau_{k, t+s}\right)\right]^{-1}\right\}\left[w_{t+j} e_{j}\left(1-l_{t+j, j}\right)\left(1-\tau_{L, t+j}\right)\right. \\
- & \left.c_{t+j, j}\left(1+\tau_{C, t+j}\right)\right]-\sum_{j=1}^{55}\left\{\Pi_{s=1}^{j}\left[\left(1+r_{t+s}\right)\left(1-\tau_{k, t+s}\right)\right]^{-1}\right\} \\
& {\left[w_{t+j} e_{j}\left(1-l_{t+j, j}\right) \theta_{t+j}\right] \geq 0 }
\end{aligned}
$$

The parameter $\tau_{C, t}$ is the proportional consumption tax, $\tau_{K, t}$ is the proportional capital tax and $\tau_{L, t}$ is the proportional labor tax. In addition, the retirement benefits are financed through a labor tax, $\theta_{t}$. The variable $P V B_{t}$ is the present value of lifetime social security benefits of generation " $t$ " (born in year " $t$ "), ${ }^{6}$ such that:

$$
P V B_{t}=\eta_{t}+\sum_{j=1}^{55}\left\{\Pi_{s=1}^{j}\left[1+r_{t+s}\left(1-\tau_{k, t+s}\right)\right]^{-1}\right\}\left[w_{t+j} e_{j}\left(1-l_{t+j, j}\right) \lambda_{j} \theta_{t+j}\right]
$$

The first term, on the right hand side, is a component that does not depend on the labor tax paid to finance the system. The second term means that one monetary unit of labor tax paid at age $j$ will give back to the individual $\lambda_{j}$ in future benefits (measured at the value of time $T=t+j$ ). Hence, $\lambda_{j}$ is the perceived age-dependent link between contributions and benefits. From equations (2) and (3), the modified consumer budget constraint then becomes:

$$
\begin{aligned}
\eta_{t} & -\sum_{j=1}^{55}\left\{\Pi_{s=1}^{j}\left[1+r_{t+s}\left(1-\tau_{k, t+s}\right)\right]^{-1}\right\}\left[w_{t+j} e_{j}\left(1-l_{t+j, j}\right)\left(1-\lambda_{j}\right) \theta_{t+j}\right] \\
& =\sum_{j=1}^{55}\left\{\Pi_{s=1}^{j}\left[1+r_{t+s}\left(1-\tau_{k, t+s}\right)\right]^{-1}\right\}\left[w_{t+j} e_{j}\left(1-l_{t+j, j}\right)\left(1-\tau_{L, t+j}\right)\right. \\
& \left.-c_{t+j, j}\left(1+\tau_{C, t+j}\right)\right] \geq 0
\end{aligned}
$$

The consumer maximizes (1) subject to the budget constraint (4) and to the constraint that the demand for leisure cannot be larger than one for each individ-

\footnotetext{
${ }^{6}$ The term $e_{j}$ captures a job-experience productivity factor, represented by a second-degree polynomial for experience.
} 
ual. $^{7}$ Solving the consumer problem for consumption and leisure, one can get a contemporaneous expression relating consumption and leisure for the individual born at time $t:^{8}$

$$
l_{t+j}=\left[\frac{w_{t+j}^{*}}{\alpha} \cdot \vartheta_{t+j}\right]^{\rho} c_{t+j}
$$

where

$$
\vartheta_{t+j}=\left[\frac{\left(1-\left(1-\lambda_{j}\right) \theta_{t+j}-\tau_{L, t, j}\right)}{\left(1+\tau_{c, t+j}\right)}\right]
$$

and

$$
w_{t+j}^{*}=w_{t+j} e_{j}+\mu_{t+j}
$$

for every time $t$ and age $j$.

Additional algebra allows one to get the individual consumption and leisure profile over the life cycle:

$$
\begin{aligned}
c_{t+j}= & {\left[\frac{1+r_{t+j}\left(1-\tau_{k, t+j}\right)}{1+\delta}\right]^{\gamma}\left[\frac{\left(1+\tau_{c, t+j-1}\right)}{\left(1+\tau_{c, t+j}\right)}\right]^{\gamma}\left[\frac{v_{t+j}}{v_{t+j-1}}\right] c_{t+j-1} } \\
l_{t+j}= & {\left[\frac{1+r_{t+j}\left(1-\tau_{k, t+j}\right)}{1+\delta}\right]^{\gamma}\left[\frac{\left(1+\tau_{c, t+j-1}\right)}{\left(1+\tau_{c, t+j}\right)}\right]^{\gamma}\left[\frac{v_{t+j}}{v_{t+j-1}}\right]\left[\frac{w_{t+j}^{*}}{w_{t+j-1}^{*}}\right]^{-\rho} } \\
& {\left[\frac{\vartheta_{t+j}}{\vartheta_{t+j-1}}\right]^{-\rho} l_{t+j-1} }
\end{aligned}
$$

where

$$
v_{t+j}=\left[1+\alpha^{\rho}\left(w_{t+j}^{*}\right)^{1-\rho}\left(\vartheta_{t+j}\right)^{1-\rho}\right]^{[(\rho-\gamma) /(1-\rho)]}
$$

The social security labor tax at time " $t$ " is determined endogenously from the social security balanced budget, in such a way that

$$
\theta_{t} \sum_{j=1}^{55} w_{t, j} L_{t, j} /(1+n)^{j-1}=\sum_{i=1}^{9} B_{t, 45+i} /(1+n)^{45+i}
$$

Individuals are eligible for the benefits in the year they turn 46 . The retirement benefit in year t of a $j$-year old cohort, $B_{t, j}$, will have two components: a timedependent fraction called the "replacement rate", $R_{t}$, which does not depend on the age of the individual, and the average index of monthly earnings, $A I M E_{t, j}$, which will be a function of time and age.

\footnotetext{
${ }^{7}$ In algebraic terms, $l_{t+j} \leq 1$, which is the labor force non-participation constraint. The Lagrangian multiplier $\mu_{t}$ associated with this constraint will take a positive value when the individual is effectively retired from the labor force.

${ }^{8}$ To simplify notation, I only use the time subscript for every variable. For example, $l_{t+j}$ represents the demand for leisure by a $j$-year-old individual in time $t+j$.
} 


$$
B_{t, j}=R_{t} A I M E_{t, j}
$$

In Brazil, eligibility for retirement benefits is reached through two mutually exclusive ways: one based on the number of years of contributions (35 years for men and 30 years for women) and another one strictly based on age (65 years). In this representative agent set-up, I assume only the old age eligibility criterion, but I artificially incorporate some aspects of the contribution-based criterion in the formula of calculation of benefits. The average index of earnings of an individual aged $j$ in year $\mathrm{t}$ is calculated based on two indicators: the labor income earned when the individual was 33 to 35 years old, $B_{t, j}^{L S}$, and the labor income earned at the edge of his/her eligibility for the benefits, between ages 43 and $45, B_{t, j}^{O A}$ :

$$
\begin{gathered}
B_{i, j}^{L S}=\sum_{i=1}^{3} w_{t-j+32+i} e_{32+i} L_{t-j+32+i, 32+i} \\
B_{i, j}^{O A}=\sum_{i=1}^{3} w_{t-j+42+i} e_{42+i} L_{t-j+42+i, 42+i} \\
A I M E_{t, j}=\frac{1}{6}\left\{B_{t, j}^{L S}+B_{t, j}^{O A}\right\}
\end{gathered}
$$

At any time $t$, the government tax revenue consists of three possible tax instruments: a proportional consumption tax rate $\tau_{C, t}$, a proportional labor tax $\tau_{L, t}$ and a proportional capital tax $\tau_{K, t}$. The aggregate tax revenue is given by

$$
T_{t}=\tau_{C, t} C_{t}+\tau_{K, t} r_{t} K_{t}+\tau_{L, t} \cdot w_{t} L_{t}
$$

where $C_{t}, K_{t}$ and $L_{t}$ are respectively the aggregate consumption, capital and labor supply at time $t$, as defined below.

Assuming there is no Ponzi Game, the government budget constraint (excluding social security) will be:

$$
\sum_{t=0}^{N}\left[\Pi_{s=0}^{t}\left(1+r_{s}\left(\left(1-\tau_{k, s}\right)\right)^{-1}\right)\right] T_{t}=\sum_{t=0}^{N}\left[\Pi_{s=0}^{t}\left(1+r_{s}\left(1-\tau_{k, s}\right)\right)^{-1}\right] G_{t}+D_{0}
$$

where $D_{0}$ is the stock of outstanding debt in the initial year and $G_{t}$ is the government consumption.

The model has a single production sector that is assumed to behave competitively, by using capital and labor subject to a constant-returns-to-scale production function. Capital is assumed to be homogeneous and the depreciation rate is assumed to be zero. The production function is assumed to have a Cobb-Douglas form such that 


$$
Y_{t}=\Phi K_{t}^{\kappa} L_{t}^{1-\kappa}
$$

where $Y_{t}$ is the net national income, $K_{t}$ is the capital stock and $L_{t}$ is the aggregate labor supply at time $t$, while $\Phi$ is the technological constant. Aggregate labor is such that

$$
L_{t}=\sum_{j=1}^{55}\left(\frac{1}{1+n}\right)^{j} e_{j} L_{t, j}
$$

that is, the sum of effective labor supplied by each individual cohort alive in year $t$. The supply of capital by households at time $t, K_{t}$, will be a function of the sum of accumulated assets of consumers indexed $j$ minus the stock of government debt at $t$ :

$$
K_{t}=\sum_{j=1}^{55}\left[\frac{1}{1+n}\right]^{j} A_{t, j}-D_{t}
$$

where $A_{t, j}$ is the stock of assets owned by the cohort aged $j$ in year $t$.

\section{Parameterization of the Initial Steady State}

\subsection{Policy parameters}

In the initial steady state, the simulation procedure requires a balanced budget. In terms of the model, this will mean a constant debt stock ratio (with respect to capital stock) and exogenous marginal tax rates. The simulation procedure then calculates the total revenue (excluding social security revenues) and the government debt service expenditure. In order to balance the budget, the direct government consumption is obtained endogenously as a residual in the steady state, and then kept constant during the rest of the transition. In other words, the government deficit is allowed to vary during the transition, but every change occurs through tax revenue and debt service, and not through government consumption.

The values for the steady state are intended to match the values of the variables for the Brazilian economy in the second half of the 1990s. In this section, I give a brief overview of the calculation methods for each of the assumed policy parameters.

\section{Tax Policy}

I assume a proportional consumption tax rate $\left(\tau_{C, t}\right)$ of $15 \%$, a proportional capital tax rate $\left(\tau_{K, t}\right)$ of $13 \%$, and a proportional labor tax of $20 \%\left(\tau_{L, t}\right)$ (excluding the social security tax).

The total tax revenue amounts to $30.6 \%$ of GDP in 1998. Excluding social security income, which is kept in a separate budget in the model, the revenue tax 
is equal to $25.6 \%$ of GDP. In the simulations, I am considering consumption taxes summing $9.31 \%$ of GDP, "income" taxes revenues summing $11.78 \%$, and labor taxes revenues of $3.18 \%$ of GDP. ${ }^{9}$ Only the regular state and federal value added taxes (ICMS and IPI) and the tax on imported goods, totaling $9.31 \%$ of GDP, are considered consumption taxes. The consumption tax base is the household consumption in 1998, which represented $63.6 \%$ of GDP. As a result, the effective proportional tax rate is equal to $14.64 \% .^{10}$

\section{Social Security System}

The social security tax rate is derived endogenously under the assumption of a balanced budget. Nonetheless, I chose the utility and technology parameters in order to match an effective social security tax rate close to the $10.3 \%$ rate that I estimated for the Brazilian economy. ${ }^{11}$

In the initial steady state, the replacement rate is set equal to $100 \%$ of the average index of monthly earnings. ${ }^{12}$ Although the current system imposes caps on contributions and benefits, I rule out those caps in the benchmark set-up. I adopt this assumption because, despite the presence of caps on benefits in the Brazilian system, the average retirement benefit paid is well below the capped value. $^{13}$

I assume that contribution-benefit links are zero for every age, except for ages within a three-year range of retirement (53 to 55 , and 63 to 65 years old) and hence social security contributions are entirely seen as a tax for most of the life

\footnotetext{
${ }^{9}$ The total tax revenue in the model represents $95 \%$ of the actual amount in 1998.

${ }^{10}$ The concept of income used here is broader than usual, including additional taxes on corporate revenues and property taxes, totaling $11.78 \%$ of GDP. Corporate tax revenues and property taxes do not have exactly the same tax bases as stricto sensu income tax, but the model is not sophisticated enough to allow for such differences. Under perfect competition, corporate revenue tax will be equivalent to a tax on labor and capital inputs. After 2001, PIS/PASEP and COFINS started to present characteristics closer to regular consumption taxes, but studying the impact of such changes is beyond the scope of this paper.

${ }^{11}$ Such effective tax rate is substantially smaller than the nominal tax rate due to noncompliance and to the presence of caps on the tax incidence. The social security tax revenue was equal to $5.06 \%$ of GDP in 1998 . The tax base is equivalent to $48.7 \%$ of GDP and the resultant payroll tax was $10.32 \%$.

${ }^{12}$ During the transition, the replacement rate is set equal to $100 \%$ from $t=0$ to $t=10$. From $t=11$ to $t=55$, it falls linearly to zero, capturing the idea that the first ten generations of retirees (those already retired when the payroll tax is zeroed) get the full benefits, and those starting to retire after the reform starts obtain a retirement benefit that is proportional to the number of years they contributed to social security. After $t=56$, the replacement rate will be zero until $t=150$.

${ }^{13}$ In 1997 dollar values, the benefits could not be larger than US\$11.265 or smaller than US\$1.344.Using data from PNAD-1997, I calculate the yearly average wage for male workers aged 53, 54, 55, 63, 64 and 65 years, and then find the corresponding benefit, assuming a replacement rate equal to one. The calculated benefit would be US\$ 8.534, which is well below the upper bound of US\$11.265 for 1997. The proportion of workers earning above such cutoff was only $18 \%$ in 1997.
} 
cycle. Such assumption is close to correct given the fact that rules change at such a high frequency that no connection between contributions and benefits persists.

\subsection{Preference and technology parameters}

\section{Parameters of the Utility Function}

Issler and Piqueira (2000) estimate the intertemporal elasticity of substitution $(\gamma)$ at 0.20 for a constant relative risk aversion (CRRA) utility function. However, their utility function does not have leisure choice, as I have in my model. Soriano and Nakane (2003) included leisure in their utility function, but they added preference for money holdings.

They do not reject a unit value for the elasticity of intertemporal substitution. Such a wide variability of estimates is a consequence of different databases as well as different specifications. In my benchmark, I use 0.35 , which is close to Issler and Piqueira (2000) and allows me reasonable steady state values for the social security effective tax rate.

There are several estimates for the pure rate of time preference $(\delta)$ for the Brazilian economy. Issler and Piqueira (2000) found $12.33 \%$ for annual data using the CRRA utility function without leisure. Soriano and Nakane (2003) found a lower estimate from quarterly data (9.7\%), and Araújo and Ferreira (1999) obtained $6.89 \%$ through calibration. I use $1.5 \%$, because simulations are very sensitive to larger values. ${ }^{14}$ The reason for such large sensitivity is that the initial debt stock is substantially large, and increases in the intertemporal discount rate shrink savings in such a manner that they lead interest rates to unrealistic values.

There are a few estimates for the intratemporal elasticity of substitution $(\rho)$. Soriano and Nakane (2003) found 1.36, but with a different utility function, as already mentioned. I assume 1.1. Leisure preference parameter $(\alpha)$ is set to 0.29 in order to get a realistic social security tax and labor supply.

\section{Parameters of the Production Function}

Estimates for the wage profile are obtained from PNADs 1976-1998, both controlling and not controlling for cohort-specific effects on earnings. Experiencerelated wage differentials are very sensitive to the econometric specification. I prefer to adopt the age profile generated in the regression that does not control for cohort effects, since it generates more realistic life cycle labor supply profiles in the steady state. When adapting the estimated coefficients to the model, one has to be careful to correctly redefine them in such way that a person aged 1 year old in the model gets a productivity factor equivalent to a worker aged 21 in real life. This means that the new estimates, adapted to the features of the model, generates the following age-wage profile, for each age $j, 1 \leq j \leq 55$ :

\footnotetext{
${ }^{14}$ Convergence is not reached for transition under larger values.
} 


$$
w_{t, i}=w_{t} e_{j}=w_{t} \exp \left\{-.2314+.0529 . j-.00093 . j^{2}\right\}
$$

It is well known that for a Cobb-Douglas production function, factor shares are constant, and the capital share in income equals the capital intensity parameter, $\kappa$. I assume a value of 0.50 for the capital income share in total income, which is larger than values found for developed countries. ${ }^{15}$

\subsection{Demographic parameters}

Population growth has slowed during the last 30 years in Brazil. In the benchmark economy, the growth rate of the population is assumed to be constant at $1.9 \%$ a year. Such a growth rate lies between the average growth in the period $1970 / 2000(2.02 \%)$ and the average growth in the period 1980/2000 (1.79\%). Another demographic assumption is that individuals live up to 75 years in this economy, close to the current life expectancy of those individuals who reach the age of 21 in Brazil (72 years).

\subsection{Calibration of the initial steady state}

Solution to the equilibrium of the economy consists in solving a complicated set of nonlinear equations using an iterative technique often referred to in the literature as the Gauss-Seidel method. In each step, the algorithm starts with guesses of a subset of endogenous variables, and initially treats these variables as exogenous. When the solution to these guessed variables equals the guessed value, a true solution to the full system has been found. Otherwise, the solution is not consistent with the values of the guessed endogenous variables, and new guesses are tried by linearly combining the two sets of values of the previous iteration. First, the algorithm solves for the initial steady state, before the policy change is implemented, then solves for the final steady state to which the economy eventually converges after the policy change, and ultimately solves for the transition path that the economy takes between these two steady states. Some simulations, such as social security privatization with debt accumulation for some fixed number of years, require solving simultaneously for the transition path and the final steady state. In each process, the simulation method assumes perfect foresight for all but those individuals living before the policy change.

The simulation procedure is designed in such a way that the imputation of an exogenous "debt ratio" (the government debt stock as a proportion of the stock of capital) is needed. I estimate a debt ratio of $15 \%$ of the capital stock, which

\footnotetext{
${ }^{15}$ A value of 0.40 is obtained by Gomes et al. (2003) from the Brazilian National Accounts. They consider part of the self-employed earners' income as labor income while I assume this as only capital income. The literature finds smaller values for developed countries. For the U.S., Kotlikoff (1996) assumes a capital income share of $25 \%$ of the national income. In general, values between $25 \%$ and $35 \%$ are found in the literature.
} 
is close to the one observed for the Brazilian economy in the period 1995-2000. ${ }^{16}$ Government spending is exogenous, and it is calculated by the difference between total tax revenue and debt service.

The steady state equilibrium when the social security system follows a PAYG rule is meant to reproduce key macroeconomic statistics of the Brazilian economy. Table 1 summarizes the main characteristics of the initial steady state. The endogenous social security tax is $10.38 \%$. The capital-output ratio is 2.55 , close to that calculated by Gomes et al. (2003). The ratio of the government debt over the GDP is $36 \%$, close to the average between 1995 and 2000 . The net national saving rate is $4.9 \%$ of GDP, close to the $4.46 \%$ of GDP that was observed on average from 1995 to $1998 .{ }^{17}$ Under the initial steady state calibration, the marginal productivity of capital $(17 \%)$ is much larger than the population growth $(1.9 \%)$.

\section{An Overview of the Alternative Reforms}

In this section, I present the different experiments simulated in the paper, which are summarized in table A.2. In experiment A, the social security labor tax is reduced to zero in year $T=1$. At the same time, the replacement rate $R_{t}$ goes to zero instantaneously, which implies a $100 \%$ cut in retirement benefits. Capital, labor and consumption tax rates are made endogenous, in order to balance the government budget in each year of the transition.

In experiments B, C, D and E, the social security tax is zeroed in year $T=1$, but the retirement benefits are phased out to zero over a 55-year period. The idea is to preserve the claims to retirement benefits for the individuals alive in year $T=1$. In effect, the replacement rate $R_{t}$ is kept at $100 \%$ until year 9 , when the youngest retiree of year $T=0$ dies. In year $T=10, R_{t}$ starts falling at a constant rate until it reaches zero in $T=55$.

While benefits are gradually eliminated, in year $T=1$ one specific tax rate is chosen to replace the old social security tax for financing the remaining benefits. The chosen tax rate is made endogenous, while the other three tax rates are kept at the same level as they were in $T=0$. In all of these four experiments, the endogenous tax rate returns to its initial level, in some year $T^{*}$, which depends on the experiment. In $T^{*}+1$, every tax rate is made endogenous, constrained to generate the same revenue share as in $T=0 .{ }^{18}$ In experiment $\mathrm{B}, \mathrm{C}$ and $\mathrm{D}$, the

\footnotetext{
${ }^{16}$ Assuming a capital-output ratio of 2.6 based on Gomes et al. (2003) and debt-GDP ratio of $39 \%$ over time, one can get such number.

${ }^{17}$ The gross saving rate was atypically low in 1998 , amounting to $17.43 \%$ in 1998 , especially because of the public sector deficit. Hence, I consider the average saving rate in the period 1995/98 as the benchmark saving rate in the calibration of the initial steady state. The average saving rate was $19.46 \%$ of GDP for that period. Discounted for depreciation of physical capital of approximately $12 \%$, and for average foreign savings (equivalent to the transaction account deficit) of $3 \%$ in $1995 / 1998$, one can find an average net national saving rate of $4.46 \%$ of GDP for Brazil in 1995/1998.

${ }^{18}$ Capital tax revenue is kept at $26.2 \%$, consumption tax revenue at $38.43 \%$ and labor tax at
} 
consumption, capital and labor tax rates are temporarily set as endogenous. In Experiment E, the government runs a deficit for seven years, and then the tax rates are adjusted instantaneously in order to balance the budget.

Experiments $\mathrm{F}$ and $\mathrm{G}$ assume that the social security reform is previously announced. In other words, the replacement rate $R_{t}$ is kept constant until $T=$ 19. In year $T=20, R_{t}$ is abruptly reduced to zero. The social security tax is endogenously determined to balance the social security budget. In effect, as soon as the replacement rate goes to zero, $\theta_{t}$ falls to zero. In experiment $\mathrm{F}$, the three tax rates are made endogenous in $T=1$ in order to balance the government budget (excluding social security). In experiment $\mathrm{G}$, the tax rates are set exogenous at the initial steady state level until year $T=20$, and the government is allowed to run a budget surplus. In $T=21$, the tax rates are set endogenous in order to balance the budget.

Experiments $\mathrm{H}$ to $\mathrm{K}$ refer to partial reforms in the PAYG system. In exercise $\mathrm{H}$, the replacement rate $R_{t}$ is phased out until reaching $30 \%$ in $T=60$. The last three exercises assume that the replacement rate is kept at $100 \%$, and the only change is the elimination of the social security tax and replacement by some other tax. In Experiment I, the social security tax is zeroed in $T=1$ and the consumption tax rate becomes endogenous in order to balance the government budget. In Experiment J, an "income tax" is levied to replace the social security tax. $^{19}$ In Experiment $K$, the labor tax is replaced by a tax on capital income in $T=1$.

\section{Discussing the Long Run Impacts of the Reform ${ }^{20}$}

The PAYG system has two key components: the compulsory accumulation of "social security assets" (which yield a below-market interest rate) and the taxation of labor earnings as a way to finance such scheme. Privatizing the system leads to a substantial welfare improvement, under the assumed parameterization, and assuming that the government runs a balanced budget during the whole transition. $^{21}$ An individual born in $\mathrm{T}=150$ will be $30 \%$ better off than under the old

$\overline{35.37 \% \text { of the total revenue (excluding }}$ social security).

${ }^{19}$ In particular, "income tax" is defined as a proportional tax on both capital and labor tax income. The portion of the capital and labor taxes is endogenously determined in order to match the new revenue requirements, according to the equation below:

$$
T_{t}=\tau_{C, t} C_{t}+\left(\tau_{K, t}+\tau_{I, t}\right) r_{t} K_{t}+\left(\tau_{L, t}+\tau_{I, t}\right) w_{t} L_{t} .
$$

\footnotetext{
${ }^{20}$ Table 3 describes the path of national income during the 150 years following the reform announcement, for each of the 11 alternative reforms. Table 4 presents the welfare gain (or loss) of the agents born between $T=1$ and $T=150$. The analysis of this section is entirely based on these two Tables.

${ }^{21}$ The labor tax falls from $30.4 \%$ to $16.3 \%$, the consumption tax falls from $15 \%$ to $11.6 \%$ and the capital tax falls from $13 \%$ to $10.7 \%$.
} 
PAYG. ${ }^{22}$ The national income is $21 \%$ larger and aggregate consumption increases by $26 \%$. The stock of domestic capital increases by $36 \%$.

The rationale behind such substantially positive welfare effects is the difference between the low implicit return on the social security "assets" and the high return on savings. The fact that the PAYG system assumed is not actuarially fair, having a below-market implicit rate of return, is determinant for understanding why its elimination will imply more wealth accumulation than before. As a result of larger accumulation of lifetime wealth, general equilibrium effects will lead to larger aggregate capital and higher marginal productivity of labor in the long run.

In addition, the distortions in the labor supply resulting from payroll taxation are eliminated, with large welfare effects. The reduction of the taxation on labor earnings will imply a substantial fall in the demand for leisure as a proportion of the lifetime income. So, higher labor supply and larger capital accumulation jointly explain the growth in national income.

Long run macroeconomic and welfare effects of the reforms will depend on the type of tax structure as well as on the amount of the stock of government debt in the new (fully funded) steady state. Debt accumulation substantially worsens the long run results. When the debt stock increases during the first seven years of the transition, growing from $36 \%$ to $74 \%$ of the GDP, the tax rates must be higher to finance the debt services in the new steady state. Labor tax falls from $30 \%$ to $23 \%$, but capital and consumption tax rates slightly increase. The result is a much smaller increase in national income $(3.6 \%)$ and in individual welfare $(6.7 \%)$.

Oppositely, when the debt stock is reduced during the transition, the long run equilibrium under full privatization will have lower average tax rates, and hence larger national income. This is the case in Experiment G, when the reform takes place only in $T=20$, and the tax rates are kept constant until then. General equilibrium effects lead to income growth and larger tax revenue, with subsequent debt reduction. In the long run, the debt stock falls from $36 \%$ to $26 \%$ of the GDP, national income grows by $22.1 \%$, and individual welfare increases by $32 \%$.

Under the assumed parametric assumptions, the magnitude of the welfare effects are substantial even when the replacement rate is not entirely phased out, being reduced from $100 \%$ to $30 \%$. Experiment $\mathrm{H}$ is meant to replicate more realistic setups for the privatization, when a residual PAYG is kept to finance the retirement of the poor. Under such scheme, the PAYG system is not fully eliminated, and a remaining labor tax finances the reduced retirement benefits. The switch to this mixed scheme still induces higher capital accumulation, and substantial welfare effects. The national income will be $14 \%$ larger and the individuals

\footnotetext{
${ }^{22}$ One measure of these utility differences is the equivalent percentage increase in full lifetime resources (assets plus the present value of earnings based on working full time) needed in the original PAYG regime to produce each cohort's realized level of utility under the specified alternative regime. I will use the concept of rest of life (ROL) wealth equivalent, instead of lifetime wealth equivalent.
} 
will be $20.7 \%$ better off under such a scheme.

A substantial part of the welfare gains from the elimination of the PAYG system comes from the distortions in labor supply caused by the high labor tax. Even when the PAYG is kept unchanged, and a consumption tax is chosen to finance retirement benefits (Experiment I), there are substantial welfare gains in the long run (13\%). It is well known that there is an equivalence between labor and consumption taxation, since these are different ways to tax lifetime consumption. So, why does national income grow by $8.3 \%$, just by switching from labor to consumption taxation? This happens because of the double taxation over the initial elderly, which induces accumulation of physical capital and larger real wages for the unborn generations.

Replacing the labor tax by a capital tax has entirely different long run consequences. The life cycle consumption profile becomes flatter than under the initial steady state, as a result of the substitution effect. The consequent crowding out of capital is compensated by a higher labor supply, and the national income hardly changes, increasing by $1.3 \%$. In contrast, individual well-being will improve by $7.8 \%$ in the long run. ${ }^{23}$ The after-tax labor earnings are larger both because of the effect of capital accumulation on wages and because of the reduction of labor taxation.

Long run results are sensitive to parametric assumptions, although the effects of the reforms are still sizeable for parametric assumptions around the benchmark values. For example, changing the intertemporal substitution from 0.35 to 1 decreases the resultant income growth of social security privatization from $20.5 \%$ to $16 \%$. The argument behind this fall is that the leisure profile becomes very steep, lowering the average retirement benefits. Social security tax rate becomes smaller in the initial steady state and its elimination does not cause as much as benefit as under the benchmark parametric assumptions. ${ }^{24}$ In general, long run changes are not too sensitive to parameter assumptions, as shown in table A.5.

\section{Discussing Transitional Issues about Privatization}

In the long run, the magnitude of the macroeconomic and welfare effects of reforming social security will depend on the degree of retirement benefit cuts. In this section, I discuss those transitions that assume the elimination of the PAYG in the long run. If there is no variation in the debt stock, the remaining benefits will determine the size of the tax burden in the new steady state, and the transitional path of the tax rates will not matter for the long run results of the reform. Full elimination of benefits leads to about $30 \%$ of welfare improvement. Keeping the replacement rate at $100 \%$ leads to welfare effects between $5.6 \%$ and $13 \%$, depending

\footnotetext{
${ }^{23}$ If the social security labor tax is replaced by an income tax instead, the welfare gains are slightly lower $(5.6 \%)$, and the national income grows by $1.8 \%$.

${ }^{24}$ Sensitivity analysis is always done here without recalibration of the initial steady state. In other words, I change the value of the tested parameter, keeping everything else unchanged.
} 
on the type of tax switch.

Why do we care for transitional paths? The reason is that the initial generations and their respective offspring will not benefit from macroeconomic environment in a distant future, when they will be already dead. However, those are the individuals who will build political coalitions to carry out the reform, choosing whether or not to undertake it. Hence, knowing how the current generations and those who will be alive in a near future are affected by the alternative reforms will give some insights about which type of reform will end up being chosen.

In this model, the only source of heterogeneity is given by the stage of the life cycle the individual will be in at the moment of the reform, which will determine the lifetime budget constraints he/she faces. Depending on the transitional tax path, some generations will lose and others will gain. One could think that the generations alive in $T=1$ will vote to choose which transitional scheme will be followed. The outcome of the intergenerational conflict would determine how radical the reform would be as well. In what follows, I look at how each type is affected by the reforms, and how this may influence their decision to vote. ${ }^{25}$

The Figures below give a hint on how the initial generations will be affected by different tax schemes, based only on their life cycle position when the reform starts. Individuals older than 62 are essentially asset owners who are consuming their entire wealth, since there is no bequest motive (figure 1). This elderly group is strongly affected by an increase in the consumption tax rate. As figure 2 shows, the individuals younger than 44 earn most of their income from labor supply. This group is especially a target of a labor tax, and should gain in case of reduction in the social security labor tax. Individuals older than 45 have already accumulated enough assets to have most of their income coming from this source. A tax on capital will evenly distribute the tax burden across these middle-aged and elderly individuals. Obviously, a tax on retirement benefits will affect almost exclusively the retirees alive in year $T=1$.

\footnotetext{
${ }^{25}$ I do not look for a voting equilibrium because such outcome must be dynamically consistent. For example, individuals alive in $T=0$ might decide to carry out a transition through consumption tax, but one must look if the future generations would repeat such choice. If not, agents in year $T=0$ must take this into account when deciding for voting for a consumption-based transition. Such interactions would involve more computationally-demanding simulation methods, and this is not what I intend here. See for example papers by authors such as Boldrin and Rustichini (1998) and Cooley and Soares (1999), which model political equilibrium specifically related to the issue of social security reform.
} 


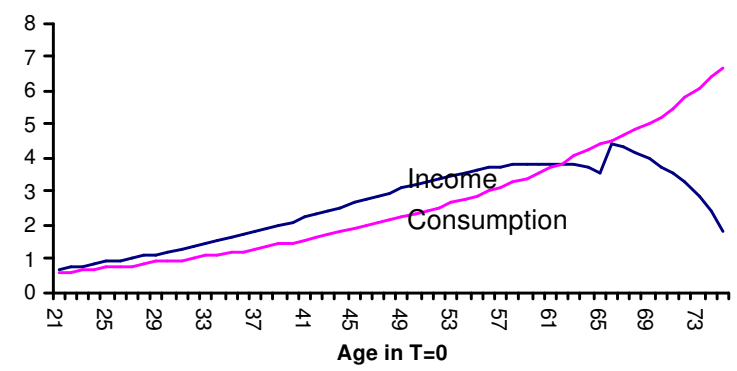

Figure 1

Life cycle after tax consumption and income profile, initial steady state

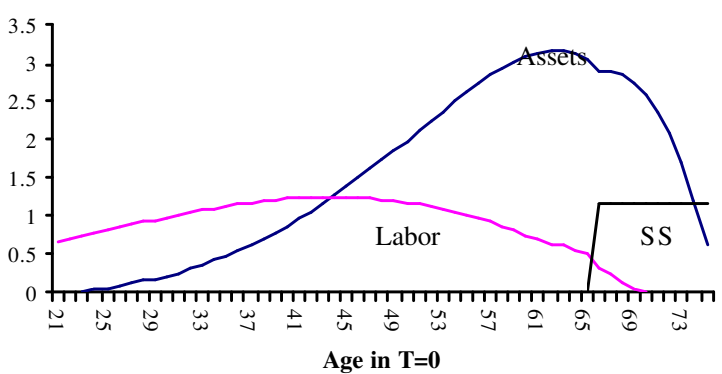

Figure 2

Net income component over the life cycle

\subsection{Full privatization financed by the generations alive in $\mathbf{T}=\mathbf{1}$}

Balanced budget transitions will have completely different "short run" macroeconomic and welfare impacts depending on which sort of tax replaces the social security tax. If an immediate cut in retirement benefits is implemented in $T=1$, the saving rate increases sharply and convergence is speeded up (Experiment A). The increase in savings is due to both an increase in labor supply and a decrease in consumption of the middle-aged and elderly individuals. In $T=19$, national income is $12 \%$ larger as a result of faster capital accumulation. Table 6 shows the welfare impact on the generations alive in $T=1$. The youths benefit substantially from the parallel cut in retirement benefits and labor taxes. An individual born in $T=1$ will be $15 \%$ better off, while the individual dying in $T=1$ is $15 \%$ worse off. The welfare loss is concentrated among individuals older than 60. Such a "fascist" policy is similar to "confiscating assets from the elderly". 
When the phased-out benefits are financed by a consumption tax, the tax burden is more evenly spread, but it will affect mostly those who consume a higher share of their income - the old individuals. Taxing consumption works as a lump sum tax for the elderly, who lose about $4 \%$ in wealth equivalent, compared to the status quo. Capital accumulation is speeded up and the national income will be $6 \%$ higher in $T=19$. The fast growth will make the youths substantially better off $(8 \%)$ through higher real wages.

Replacing the labor tax with a tax on capital income shifts the tax burden from the elderly to middle-aged individuals (Experiment C). A 50-year-old agent will be $2.2 \%$ worse off, compared to $0.9 \%$ under the consumption tax scheme. A 70-year-old agent will lose $1.9 \%$ of his/her remaining lifetime utility under the capital tax scheme. The very young would rather have the transition under the capital tax because they will only pay capital income tax when they are older, but by that time, the tax rate will have already lowered. Their lifetime income will be $8.9 \%$ larger under the capital tax scheme and $7.9 \%$ under consumption tax. Because taxing capital leads to a reduction in capital stock, the national income suffers an initial sluggishness, converging slowly to the new steady state.

Experiment D phases out the social security tax. None of the cohorts alive in $T=1$ will enjoy significant welfare gain. The tax burden is evenly distributed across those generations, and national income increases at a slow pace.

\subsection{Transferring the tax burden to future generations}

In Experiment $\mathrm{F}$, the social security tax and retirement benefits are eliminated altogether in $T=20$, which under perfect foresight works like a 20-year-in-advance policy announcement. The future reduction in benefits forces a higher capital accumulation, resulting in national income growth prior to $T=20$. National income will be $1 \%$ larger in $T=19$.

The only difference between this experiment and the "Cold Turkey" is the timing in which the reform occurs, but this makes a lot of difference under an environment where generations are not attached through bequest motive. ${ }^{26}$ Under announcement, the initial elderly will not pay a dime, since they will be dead when the retirement benefit is zeroed. Those that in some way will be affected by benefit cuts will smoothen consumption in order to prepare for such income loss, which will substantially decrease the impact of the transition. In a nutshell, "announcement" transfers the tax burden from the elderly to all those alive in $T=20$, substantially postponing the welfare benefits of full privatization.

\footnotetext{
${ }^{26}$ Adding bequest does not change most of the results in this paper, unless one allows for negative bequest. Most of the tax schemes here imply a heavy tax burden for the elderly, and the resulting income effects of such schemes could only be attenuated if those elderly generations borrow from future generations' earnings. Otherwise, bequests will be zero for most of the transitions. An exception is the transitions financed by debt accumulation, when debt works as a device that replaces negative bequest.
} 
Another insightful way to transfer the burden of privatization to future generations is by carrying debt during the first years of transition, and then making the tax adjustment some years later. Such scheme is very appealing to the generations alive in $T=1$, since they enjoy the tax relief and its macroeconomic effects. Because the phase-out respects the acquired rights of those already earning benefits (since they paid in full for such right), the debt scheme makes the initial elderly better off. The 70 -year-old agent will have a $0.7 \%$ increase in benefits. Individuals younger than 40 in $T=1$ enjoy substantial welfare gain compared to the labor tax transitional scheme or to announcement schemes. A 21-year-old individual is $3.5 \%$ better off under such scheme than under the old PAYG, notwithstanding being alive during the tax overshoot in $T=7$.

The other side of the coin is a deep welfare loss for future generations. Individuals born between years 6 and 36 will be worse off than under the old PAYG. In particular, individuals born in $\mathrm{T}=10$ will suffer a $2.2 \%$ decrease in their lifetime utility. Debt accumulation will lead to the crowding out of the capital stock, which is reinforced by the tax adjustment in $\mathrm{T}=8$. National income falls after $T=8$, being still at $98 \%$ of its initial value by year $T=25$. In the long run, full privatization will lead only to an increase of $3.6 \%$ in national income.

One can say that debt accumulation is definitely more appealing than the announcement/postponing policy to the initially alive individuals, except for those between ages 55 and 65 . Moreover, it is more attractive than phasing out the social security labor tax, except for those between 50 and 55 . Compared to the transitions financed either by capital tax or by consumption tax, the debt-financing scheme does not lead to such drastic redistribution of lifetime income among generations alive in $T=1$, leaving the initial elderly much better off.

\subsection{The political economy of the social security reforms}

One can imagine that the choice of the tax base may be the result of bargain among the agents alive in $T=1$, or may be decided by a majority voting mechanism. The difficulty in modeling and simulating reforms as a result of political interactions comes from the dynamic properties of this model. In this case, any commitment to reform in a given direction would not be credible. A political equilibrium with dynamic consistency requires that agents think about all possible future outcomes when new agents (voters) are born. Although such ambition is beyond the scope of this paper, one can think about the political appeal of the reforms studied here when agents are myopic with respect to macroeconomic impacts of future changes in the social security institutions. In other words, what would the choice be like if agents think that their decision will not be reconsidered in the future?

As the welfare analysis shows, there is an intrinsic intergenerational conflict among the generations alive in $T=1$ : the elderly like announcement or debtfinance, the youths like capital and consumption tax financing, and the middle- 
aged prefer to stay in the PAYG system as it was originally conceived. Naturally, the outcome of the conflict will depend on demographic characteristics of the country.

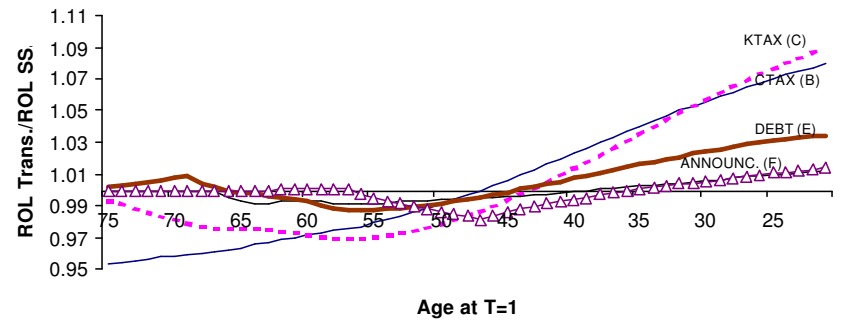

Figure 3

Welfare gain (or loss) for Cohorts alive in $T=1$

Figure 3 shows how agents would choose the complete phase-out of retirement benefits among the different forms of financing. As one can see, there is no tax scheme that is strictly preferable for every generation alive in $T=1$. Moreover, every tax scheme but the transition financed by labor taxation is the most preferred by at least one generation. Debt scheme (E) is the most preferred by those older than 67 . The previous announcement is preferred by those between 57 and 64 years old (F). The PAYG system is preferred by those between 48 and 56 years old. The consumption tax is preferred by those between 31 and 47 years of age (B), and capital tax is preferred by those below 31 years old (C). The labor tax reform is not preferred by any of the initial generations, because there is almost no redistribution involved.

The political outcome would depend on the demographic distribution of the population. I simulate voting using the true Brazilian demographic distribution, assuming that only agents alive in $T=1$ vote for the tax scheme financing privatization. The menu of options excludes Experiment $\mathrm{A}$ and those that do not consider the total elimination of the PAYG system. Because the median age in Brazil is 38 years old (among the assumed voters), the chosen tax policy will tend to favor the redistribution from the elderly to the youths. However, there is no tax scheme that is strictly preferred by more than $50 \%$ of the "voters".

The consumption tax scheme is preferred by $40 \%$ of the "voters" (item 7.A in table A.7), while the status quo PAYG is the least preferred by $42 \%$ of the "voters" (item 7.B in table A.7). However, if I omit debt accumulation and announcement from the menu options (item 7.C in table A.7), $32 \%$ of the "voters" will be better off under the status quo, compared to $40 \%$ under consumption tax and $28 \%$ under capital tax. This happens because the elderly and middle-aged are the ones in favor either of debt accumulation or postponement, and once I rule out such options, 
their votes will pool together. This may help to explain why there is a political resistance to privatize the PAYG system in Brazil. ${ }^{27}$

\section{Conclusion}

In the absence of lifetime uncertainty, social security plays no role, and the elimination of the labor tax, allowing individuals to freely allocate their savings, has strongly positive long run welfare effects. Since there is no labor productivity growth, the implicit rate of return of social security "savings" is very small, and even a slight reduction in the labor tax rate is able to produce substantial macroeconomic effects. Partial reforms that either reduce the replacement rate or switch the tax base that finances those benefits are able to produce significantly positive long run effects. Since there is no free lunch, all the conflicts about social security reform lie in transitional issues. I show that under a variety of possible transitional schemes, there is no tax path that is strictly preferred by every agent. Such lack of political consensus, generated by intergenerational conflict, may be a reason why Brazil has "chosen" not to reform its PAYG system.

The Brazilian old-age pension system works as a minimum income program, and the present value of retirement benefits, net of contributions, varies widely across individuals. A valuable extension of this research would be adding intragenerational heterogeneity.

Another possible route is to explore the political economy features of the model, finding out which possible outcomes would rise if one imposes endogenous voting, in the sense that generations would be allowed to vote in each period.

\section{References}

Araújo, C. \& Ferreira, P. (1999). Reforma tributária, efeitos alocativos e impactos de bem estar. Revista Brasileira de Economia, 53:133-166.

Ardeo, V., Beltrão, K., Giambiagi, F., \& Mendonça, J. (2004). Diagnóstico da previdência social no Brasil: $\mathrm{O}$ que foi feito e o que falta reformar. Pesquisa e Planejamento Econômico, 34(3):365-418.

Auerbach, A. \& Kotlikoff, L. (1987). Dynamic Fiscal Policy. Cambridge University Press, Cambridge.

Barreto, F. \& Oliveira, L. (2000). Transição para regimes previdenciários de capitalização e seus efeitos macroeconômicos de longo prazo no Brasil. Estudos Econônicos, 31(1):57-87.

Boldrin, M. \& Rustichini, A. (1998). Political equilibria with social security. Review of Economic Dynamics, 3:41-78.

\footnotetext{
${ }^{27}$ The model incorporates neither uncertainty nor intragenerational heterogeneity, which implies the omission of important sources of conflict over the available policy instruments.
} 
Cooley, T. \& Soares, J. (1999). A positive theory of social security based on reputation. Journal of Political Economy, 107(1):135-160.

De Nardi, M., Imrohoroglu, S., \& Sargent, T. (1998). Projected US demographics and social security. Review of Economic Dynamics, 2(3):575-615.

Deaton, A., Gourinchas, P., \& Paxson, C. (2000). Social security and inequality over the life cycle. Working paper 7570.

Ellery, R. \& Bugarin, M. (2002). Welfare implications of the Brazilian social security system. Texto para discussão 242, Universidade de Brasília.

Feldstein, M. (1974). Social security, induced retirement and aggregate capital accumulation. Journal of Political Economy, 82(5):905-926.

Gomes, V., Pessoa, S., \& Veloso, F. (2003). Evolução da produtividade total de fatores na economia brasileira: Uma análise comparativa. Pesquisa e Planejamento Econômico, 33(3):389-434.

Huang, H., Imrohoroglu, S., \& Sargent, T. (1997). Two computations to fund social security. Macroeconomic-Dynamics, 1(1):7-44.

Issler, J. \& Piqueira, N. (2000). Estimating relative risk aversion, the discount rate and the intertemporal elasticity of substitution in consumption for Brazil using three types of utility function. Brazilian Review of Econometrics, 20(2):201-239.

Kotlikoff, L. (1979). Social security and equilibrium capital intensity. Quarterly Journal of Economics, 93(2):233-253.

Kotlikoff, L. (1996). Simulating the privatization of social security in general equilibrium. National Bureau of Economic Research Working Paper 5776.

Shiller, R. (2005). The life cycle personal account proposal for social security: A review. National Bureau of Economic Research Working Paper 11300.

Soriano, L. \& Nakane, M. (2003). Real balance in the utility function: Evidence from Brazil. Banco Central do Brasil, Working Paper 68. 


\section{Appendix}

Table A.1

\begin{tabular}{lcc}
\hline & Simulated & Actual \\
\hline Interest rate(1) & $17.2 \%$ & $18.0 \%$ \\
Social security labor tax & $10.38 \%$ & $10.32 \%$ \\
Consumption tax (1) & $15.00 \%$ & $14.64 \%$ \\
Capital tax (1) & $13.00 \%$ & $13.39 \%$ \\
Labor tax (1) (exclusive ss tax) & $20.00 \%$ & $20.74 \%$ \\
SS. benef. (\%GNP) & $4.56 \%$ & $5.43 \%$ \\
Capital-GNP & 2.557 & $3-4$ \\
Govt. debt (\%GNP) & $35.72 \%$ & $34.74 \%$ \\
Revenue (\%GNP) & $24.88 \%$ & $26.15 \%$ \\
Total revenue* (\%GNP) & $29.45 \%$ & $31.26 \%$ \\
Interest service (\%GNP) & $6.16 \%$ & $7.67 \%$ \\
Govt. consumption (\%GNP) & $18.72 \%$ & $20.43 \%$ \\
National saving rate (\%GNP) & $4.85 \%$ & $4.56 \%$ \\
\hline *It includes social security revenue. & & \\
(1) Exogens & &
\end{tabular}

(1) Exogenous

Table A.2

Theoretical alternatives for financing the transition

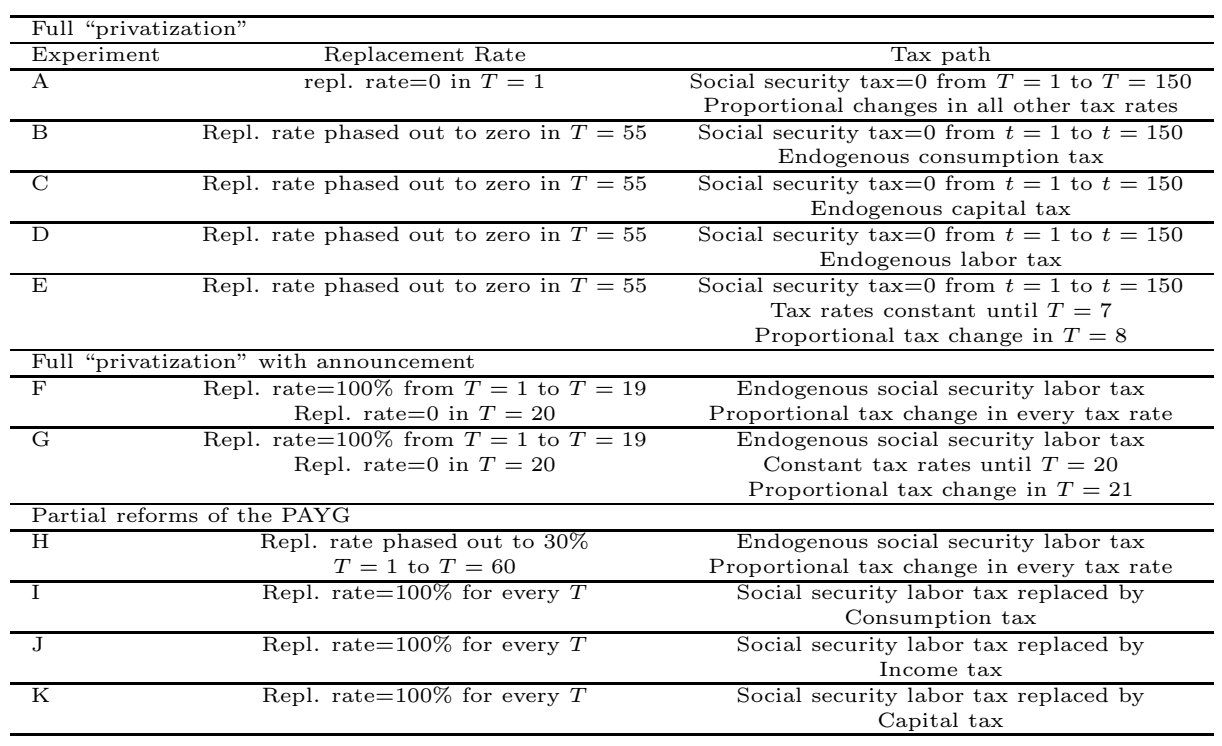


Table A.3

Transition-income

\begin{tabular}{ccccccccccc}
\hline & Year & 1 & 5 & 10 & 19 & 25 & 50 & 75 & 100 & 150 \\
\hline A & Cold Turkey & 102.8 & 105.4 & 108.4 & 112.0 & 113.5 & 117.3 & 119.1 & 119.9 & 120.5 \\
B & Consumption & 101.5 & 102.5 & 103.9 & 106.3 & 107.7 & 112.9 & 116.9 & 119.0 & 120.5 \\
C & Capital & 102.1 & 101.9 & 101.9 & 103.0 & 104.2 & 111.3 & 116.3 & 118.7 & 120.5 \\
D & Labor & 99.8 & 100.0 & 100.3 & 101.5 & 102.5 & 109.2 & 115.4 & 118.3 & 120.5 \\
E & Debt - 7 & 102.2 & 102.0 & 98.6 & 98.1 & 98.0 & 98.4 & 100.5 & 101.8 & 103.6 \\
\hline F & Ant./bal.budg. & 100.0 & 100.2 & 100.4 & 101.0 & 105.0 & 112.1 & 117.1 & 119.0 & 120.5 \\
G & Ant./surpl. & 100.0 & 100.2 & 100.4 & 101.1 & 105.3 & 113.1 & 118.5 & 120.5 & 122.1 \\
\hline H & R=30\% & 100.0 & 100.3 & 100.7 & 101.6 & 102.3 & 106.1 & 110.2 & 112.5 & 114.3 \\
I & $\mathrm{R}=100 \%$, C.tax & 101.4 & 102.4 & 103.5 & 105.2 & 106.0 & 107.5 & 108.1 & 108.3 & 108.3 \\
J & $\mathrm{R}=100 \%$, I.tax & 101.2 & 101.0 & 100.9 & 101.0 & 101.1 & 101.4 & 101.6 & 101.6 & 101.8 \\
K & $\mathrm{R}=100 \%$, K.tax & 102.1 & 101.7 & 101.4 & 101.2 & 101.3 & 101.4 & 101.3 & 101.3 & 101.3 \\
\hline Year $T=0=100$ & & & & & & & & &
\end{tabular}

Table A.4

Lifetime utility-wealth equivalent

\begin{tabular}{cccccccccc}
\hline & "Birth"year & 1 & 5 & 10 & 25 & 50 & 75 & 100 & 150 \\
\hline A & Cold Turkey & $14.6 \%$ & $17.0 \%$ & $19.3 \%$ & $23.4 \%$ & $27.0 \%$ & $28.5 \%$ & $29.2 \%$ & $29.7 \%$ \\
B & Consumption & $7.9 \%$ & $9.1 \%$ & $10.7 \%$ & $15.6 \%$ & $22.8 \%$ & $26.7 \%$ & $28.4 \%$ & $29.7 \%$ \\
C & Capital & $8.9 \%$ & $9.2 \%$ & $9.8 \%$ & $13.1 \%$ & $21.4 \%$ & $26.0 \%$ & $28.2 \%$ & $29.7 \%$ \\
D & Labor & $1.2 \%$ & $2.1 \%$ & $3.6 \%$ & $9.5 \%$ & $19.6 \%$ & $25.3 \%$ & $27.8 \%$ & $29.7 \%$ \\
E & Debt - 7 & $3.5 \%$ & $0.5 \%$ & $-2.2 \%$ & $-1.1 \%$ & $1.4 \%$ & $3.8 \%$ & $5.1 \%$ & $6.8 \%$ \\
\hline F & Ant./bal.budg. & $1.4 \%$ & $2.5 \%$ & $4.7 \%$ & $15.5 \%$ & $22.8 \%$ & $26.9 \%$ & $28.6 \%$ & $29.9 \%$ \\
G & Ant./surpl. & $1.4 \%$ & $2.6 \%$ & $5.0 \%$ & $16.9 \%$ & $24.7 \%$ & $29.0 \%$ & $30.8 \%$ & $32.0 \%$ \\
\hline H & R=30\% & $1.3 \%$ & $2.1 \%$ & $3.1 \%$ & $6.5 \%$ & $13.1 \%$ & $17.2 \%$ & $19.2 \%$ & $20.7 \%$ \\
I & R=100\%, C.tax & $7.4 \%$ & $8.2 \%$ & $9.1 \%$ & $11.0 \%$ & $12.3 \%$ & $12.7 \%$ & $12.9 \%$ & $12.9 \%$ \\
J & R=100\%, I.tax & $4.8 \%$ & $4.8 \%$ & $4.8 \%$ & $5.0 \%$ & $5.2 \%$ & $5.4 \%$ & $5.4 \%$ & $5.6 \%$ \\
K & R=100\%, K.tax & $8.1 \%$ & $7.9 \%$ & $7.8 \%$ & $7.8 \%$ & $7.8 \%$ & $7.8 \%$ & $7.8 \%$ & $7.8 \%$ \\
\hline
\end{tabular}


Table A.5

Steady state changes in aggregate variables, factor returns and saving

\begin{tabular}{|c|c|c|c|c|c|c|c|c|c|c|c|}
\hline \multicolumn{5}{|c|}{$\begin{array}{l}\text { Balanced budget transition } \\
\text { Parametric assumptions }\end{array}$} & \multicolumn{7}{|c|}{ Long run effects of full elimination of the PAYG } \\
\hline$\gamma$ & $\rho$ & $\delta$ & $\alpha$ & Pop.gth. & $\mathrm{dK} / \mathrm{K}$ & $\mathrm{dL} / \mathrm{L}$ & $\mathrm{dC} / \mathrm{C}$ & $\mathrm{dY} / \mathrm{Y}$ & $\mathrm{dW} / \mathrm{W}$ & $\mathrm{dR} / \mathrm{R}$ & $\mathrm{dS} / \mathrm{S}^{(1)}$ \\
\hline 0.35 & $\frac{p}{1.3}$ & 0.015 & 0.29 & $1.9 \%$ & $36 \%$ & & $26 \%$ & $21 \%$ & $13 \%$ & $-12 \%$ & $13 \%$ \\
\hline 0.3 & 1.3 & 0.015 & 0.29 & $1.9 \%$ & $37 \%$ & $7 \%$ & $26 \%$ & $21 \%$ & $14 \%$ & $-12 \%$ & $13 \%$ \\
\hline 0.7 & 1.3 & 0.015 & 0.29 & $1.9 \%$ & $32 \%$ & $5 \%$ & $22 \%$ & $18 \%$ & $12 \%$ & $-11 \%$ & $12 \%$ \\
\hline 0.1 & 1.3 & 0.015 & 0.29 & $1.9 \%$ & $29 \%$ & $5 \%$ & $20 \%$ & $16 \%$ & $11 \%$ & $-10 \%$ & $11 \%$ \\
\hline 0.35 & 0.9 & 0.015 & 0.29 & $1.9 \%$ & $30 \%$ & $3 \%$ & $19 \%$ & $55 \%$ & $12 \%$ & $-11 \%$ & $12 \%$ \\
\hline 0.35 & 1.5 & 0.015 & 0.29 & $1.9 \%$ & $39 \%$ & $7 \%$ & $28 \%$ & $22 \%$ & $14 \%$ & $-12 \%$ & $14 \%$ \\
\hline 0.35 & 1.3 & 0.025 & 0.29 & $1.9 \%$ & $34 \%$ & $6 \%$ & $24 \%$ & $20 \%$ & $12 \%$ & $-11 \%$ & $12 \%$ \\
\hline 0.35 & 1.3 & 0.015 & 0.2 & $1.9 \%$ & $39 \%$ & $6 \%$ & $26 \%$ & $21 \%$ & $14 \%$ & $-13 \%$ & $15 \%$ \\
\hline 0.35 & 1.3 & 0.015 & 0.5 & $1.9 \%$ & $29 \%$ & $7 \%$ & $22 \%$ & $18 \%$ & $10 \%$ & $-9 \%$ & $10 \%$ \\
\hline 0.35 & 1.3 & 0.015 & 0.29 & $1.79 \%$ & $38 \%$ & $7 \%$ & $27 \%$ & $21 \%$ & $14 \%$ & $-12 \%$ & $14 \%$ \\
\hline \multirow{2}{*}{\multicolumn{12}{|c|}{$\begin{array}{ccccc}0.35 & 1.3 & 0.015 & 0.29 & \mathbf{2 . 0 2 \%} \\
\text { Links }-0.2 \text { for age } 1 \text { to } 49.0 \text { for age } 50 \text { to } 62\end{array}$}} \\
\hline & & & & & & & & & & & \\
\hline $\begin{array}{l}\text { Links } \\
0.35\end{array}$ & $\begin{array}{l}-0.21 \\
1.3\end{array}$ & $\begin{array}{l}\text { or age } 1 \text { t } \\
0.015\end{array}$ & $\begin{array}{r}49,0 \\
0.29\end{array}$ & $\begin{array}{c}\text { age } 50 \text { to } 62 \\
1.9 \%\end{array}$ & $36 \%$ & $6 \%$ & $25 \%$ & $20 \%$ & $13 \%$ & $-12 \%$ & $13 \%$ \\
\hline Wage & profile & Cohort & control & & & & & & & & \\
\hline 0.35 & 1.3 & 0.015 & 0.29 & $1.9 \%$ & $23 \%$ & $3 \%$ & $16 \%$ & $13 \%$ & $9 \%$ & $-8 \%$ & $9 \%$ \\
\hline
\end{tabular}


Table A.6

Lifetime utility-wealth equivalent

\begin{tabular}{ccccccccccc} 
& Cohort (T=1) & 21 & 30 & 40 & 50 & 55 & 60 & 65 & 70 & 75 \\
\hline A & Cold Turkey & $14.6 \%$ & $11.6 \%$ & $7.2 \%$ & $2.2 \%$ & $-1.0 \%$ & $-5.6 \%$ & $-14.3 \%$ & $-15.6 \%$ & $-14.7 \%$ \\
B & Consumption & $7.9 \%$ & $5.6 \%$ & $2.3 \%$ & $-0.9 \%$ & $-2.11 \%$ & $-2.9 \%$ & $-3.6 \%$ & $-4.2 \%$ & $-4.7 \%$ \\
C & Capital & $8.9 \%$ & $5.6 \%$ & $1.3 \%$ & $-2.2 \%$ & $-3.0 \%$ & $-2.9 \%$ & $-2.4 \%$ & $-1.9 \%$ & $-0.7 \%$ \\
D & Labor & $1.2 \%$ & $0.6 \%$ & $-0.1 \%$ & $-0.7 \%$ & $-0.8 \%$ & $-0.8 \%$ & $-0.7 \%$ & $-0.1 \%$ & $-0.1 \%$ \\
E & Debt - 7 & $3.5 \%$ & $2.5 \%$ & $0.7 \%$ & $-0.8 \%$ & $-1.3 \%$ & $-0.7 \%$ & $-0.2 \%$ & $0.7 \%$ & $0.2 \%$ \\
\hline F & Ant./bal.budg. & $1.4 \%$ & $0.6 \%$ & $-0.6 \%$ & $-1.4 \%$ & $-0.5 \%$ & $0.0 \%$ & $0.0 \%$ & $0.0 \%$ & $-0.1 \%$ \\
G & Ant./surpl. & $1.4 \%$ & $0.5 \%$ & $-0.6 \%$ & $-1.4 \%$ & $-0.5 \%$ & $0.0 \%$ & $0.0 \%$ & $0.0 \%$ & $0.0 \%$ \\
\hline H & R=30\% & $1.3 \%$ & $0.8 \%$ & $0.3 \%$ & $-0.3 \%$ & $-0.6 \%$ & $-0.8 \%$ & $-0.7 \%$ & $-0.4 \%$ & $-0.1 \%$ \\
I & $\mathrm{R}=100 \%$, C.tax & $7.4 \%$ & $5.3 \%$ & $2.3 \%$ & $-0.5 \%$ & $-1.7 \%$ & $-2.7 \%$ & $-3.6 \%$ & $-4.2 \%$ & $-4.7 \%$ \\
J & R=100\%, I.tax & $4.8 \%$ & $3.1 \%$ & $0.9 \%$ & $-0.9 \%$ & $-1.4 \%$ & $-1.6 \%$ & $-1.6 \%$ & $-1.1 \%$ & $-0.4 \%$ \\
K & R=100\%, K.tax & $8.1 \%$ & $5.1 \%$ & $1.2 \%$ & $-1.7 \%$ & $-2.5 \%$ & $-2.6 \%$ & $-2.3 \%$ & $-1.9 \%$ & $-0.7 \%$ \\
\hline
\end{tabular}


Table A.7

Voting simulation $^{(1)(2)}$

\begin{tabular}{|c|c|c|c|c|c|}
\hline \multicolumn{6}{|c|}{ 7.a - The most preferred (all included) } \\
\hline $\begin{array}{c}\text { Consumption } \\
40 \% \\
\end{array}$ & $\begin{array}{c}\text { Capital } \\
28 \%\end{array}$ & $\begin{array}{c}\text { Labor } \\
0 \%\end{array}$ & $\begin{array}{l}\text { Debt } \\
9 \%\end{array}$ & $\begin{array}{c}\text { Announcement } \\
8 \% \\
\end{array}$ & $\begin{array}{c}\text { PAYG } \\
15 \% \\
\end{array}$ \\
\hline \multicolumn{6}{|c|}{ 7.b - The least preferred (all included) } \\
\hline $\begin{array}{c}\text { Consumption } \\
14 \% \\
\end{array}$ & $\begin{array}{c}\text { Capital } \\
16 \% \\
\end{array}$ & $\begin{array}{c}\text { Labor } \\
0 \%\end{array}$ & $\begin{array}{l}\text { Debt } \\
0 \%\end{array}$ & $\begin{array}{c}\text { Announcement } \\
28 \% \\
\end{array}$ & $\begin{array}{c}\text { PAYG } \\
42 \%\end{array}$ \\
\hline \multirow{2}{*}{$\begin{array}{c}7 . \mathrm{c}-\text { The most } \\
\text { Consumption } \\
40 \%\end{array}$} & preferred & & & & \\
\hline & $\begin{array}{c}\text { Capital } \\
28 \%\end{array}$ & $\begin{array}{c}\text { Labor } \\
0 \%\end{array}$ & $\begin{array}{c}\text { Debt } \\
0 \%\end{array}$ & $\begin{array}{c}\text { Announcement } \\
0 \% \\
\end{array}$ & $\begin{array}{c}\text { PAYG } \\
32 \%\end{array}$ \\
\hline
\end{tabular}

